\title{
VERTICAL PRODUCT DIFFERENTIATION WITH SUBCONTRACTING
}

\author{
Joaquín Andaluz* \\ Department of Economic Analysis \\ University of Zaragoza, Spain
}

\begin{abstract}
The paper examines the effects of subcontracting on vertical product differentiation in a spatial competition model. It is shown that the level of differentiation is determined by the consignor's bargaining power and the ratio of final product transport costs to the cost of the input contracted. Assuming that the consignor has total bargaining power, subcontracting will imply a reduction in quality and a greater difference between qualities.
\end{abstract}

JEL classification: L14, L22, D43, C78

Keywords: Subcontracting, Vertical Product Differentiation, Spatial Competition.

* Financial support provided by the Spanish Ministry od Science and Technology (SEC2005-06522).

Corresponding address: Department of Economic Analysis, University of Zaragoza, Gran Vía 2, 50005 Zaragoza, Spain. Tel.: +34976762631; Fax: +34976761996; E-mail: jandaluz@unizar.es (J. Andaluz). 


\section{VERTICAL PRODUCT DIFFERENTIATION WITH SUBCONTRACTING}

\section{Introduction}

Subcontracting all or part of production is a common form of relationship between rival firms in many industries. While the practice was in the past thought to involve the domination of small and medium sized businesses by large firms, as Taymaz and Kilicaslan (2002) point out, its role in the development of small and medium-size establishments was finally recognised in the 1970s and 80s. Indeed, international organizations such as the World Bank and the United Nations Industrial Development Organisation now recommend industrial subcontracting.

Following Holmes (1986), we may define subcontracting as, “a situation where the firm offering the subcontract requests another independent enterprise to undertake the production or carry out the processing of a material, component, part or subassembly for it according to specifications or plans provided by the firm offering the subcontract." According to this author, there are three kinds of subcontracting, namely capacity subcontracting, specialisation subcontracting and supplier subcontracting.

The first category refers to horizontal subcontracting, since capacity subcontracting represents the disintegration of horizontal production. Nevertheless, horizontal subcontracting is a broad concept, covering a wide range of contracts between firms (see Spiegel, 1993).

The other two categories are examples of vertical subcontracting and are cases of vertical disintegration of production, which arise when two firms have vertically related technologies or assets.

Subcontracting agreements are common in the automotive, computer, telecommunications and aeronautical industries, among others. As Spiegel (1993) points out, Mazda Motor Co. produces the Ford Probe sports car, which competes with its own MX-6 model in the automobile market, and Zenith Electronics has an agreement to manufacture laptop computers for Hewlett-Packard. Likewise, McDonnell-Douglas Corporation and Lockheed were originally in competition for the production of the C-17 military aircraft, which McDonnell-Douglas won. However, Lockheed later manufactured C-17 components for McDonnell-Douglas Corporation under a subcontracting agreement (Kamien et al., 1989). 
There is an extensive literature on subcontracting and its consequences for firms' behaviour. For example, Kamien, Li and Samet (1989) looked at the phenomenon in situations where firms were initially in competition for a contract but subsequently entered into a subcontracting agreement. They showed that firms behave less aggressively at the tender stage where the terms of the subcontracting agreement are set by the first round loser.

Lewis and Sappington (1991) showed that subcontracting will occur if the subcontracted firm's cost advantage is high enough to offset the loss of control associated with the procedure.

Spiegel (1993) examined the phenomenon of horizontal subcontracting and assessed the benefits of the practice. Specifically, they showed that firms with asymmetric convex costs may opt for subcontracting to allocate production more efficiently and generate a mutually beneficial surplus. The resulting production efficiency gains allow a higher volume of total output, which implies a higher level of development.

On the other hand, there exists a close relationship between subcontracting production and location agglomeration in reality. Scott (1991) empirically studies the geography of the electronics assembly subcontract industry in Southern California and finds that electronic assembly subcontractors are strongly linked in networks of transactional interaction with both suppliers and customers, and markedly agglomerate with their main markets. Wang et al. (2002) use the data of Taiwan's census in 1991 and show that the level of firm's subcontracting activity has a positive relationship with the firm's regional agglomeration.

However, the effects of subcontracting production on product differentiation have not been analyzed theoretically in the literature.

As a rare exception we can cited the paper of Liang and Mai (2006). The authors have developed a variant of Hotelling's (1929) spatial competition model with vertical subcontracting in production in order to validate the Principle of Minimum Differentiation. The subcontracting agreement is signed by firms with a Nash bargaining process in which each firm captures a fraction of the subcontracting surplus according to its bargaining power. These authors study the two polar cases in which either the consignor or the subcontractor takes the whole subcontracting surplus in the subcontracting agreement, respectively and show that if the ratio between the transport cost of a subcontracted input and the transport cost of the finished product is sufficiently large, then the Minimum Differentiation Principle will operate, but if it is low, the Maximum Differentiation 
Principle will hold. They also look at the influence of the transport cost ratio on the decision of the subcontracted firm to subcontract or not.

This paper extends the Liang and Mai's research in a spatial competition model under vertical product differentiation. Developing a game in which the firms concerned decide locations in the first stage, set prices in the second and finally determine the volume of input contracted, it can be shown that the degree of differentiation will be conditioned both by the consignor's bargaining power and the ratio of transport costs. Assuming that the consignor has total bargaining power, subcontracting implies a higher degree of vertical differentiation.

The paper is organised as follows. Section 2 develops and solves the model, while Section 3 analyses the decision to subcontract on the part of the subcontracted firm. Section 4 presents the main conclusions.

\section{The model}

We begin by developing a version of the Hotelling (1929) spatial competition model. Let us assume a market represented by the unit interval $[0,1]$, in which the consumers are evenly distributed.

There are two firms, 1 and 2, producing the same good, $Q$, and differentiated only by location, which employ a standard intermediate input, $q$. For the purposes of simplification, we may further assume that one unit of output requires one unit of input.

Firm 1 locates its product in $s_{1}$ and firm 2 in $s_{2}$, such that $1 \leq s_{1} \leq s_{2}$. At identical prices, then, all consumers will prefer the product offered by firm 1, because it is closer to the interval in which they are distributed. This characteristic means the model may defined as vertically differentiated (Gabszewicz and Thisse, 1986).

The firms can integrate vertically through subcontracting in the input market. We shall assume that firm 1 is the consignor and firm 2 is the subcontractor. Both have constant marginal production costs, which are higher for firm 1 than for firm 2: $c_{1}>c_{2}$. Under these conditions, the firm with the higher production cost may subcontract all or part of the production of the intermediate input to firm 2, which has lower marginal costs.

The cost of transporting both the final product and the intermediate input is expressed as a quadratic function of distance. Thus, each consumer buys one unit of the final product from the firm that provides the greater surplus, defined as the difference between the reservation price and the total cost associated with the purchase. In formal 
terms, the utility of a consumer located at $\mathrm{m} \varepsilon[0,1]$ who acquires a unit of firm $\mathrm{j}$ 's product will be given by:

$$
u\left(s_{j}, m, p_{j}, v\right)=v-t\left(s_{j}-m\right)^{2}-p_{j} ; j=1,2 .
$$

where:

$-v$ denotes the reservation price, which is common for all consumers and is high enough to ensure that the market is covered.

$-p_{j}$ represents the mill price set by firm $\mathrm{j}$.

$-t\left(s_{j}-m\right)^{2}$ is the loss of utility incurred by a consumer purchasing a variant of the product that is not ideal, $t$ being the transport cost of the final product per unit of distance (in terms of product differentiation, it determines the importance of differentiation).

Under these conditions, we shall use $\mathrm{x}$ as the expression of the location of the marginal consumer, which is given by:

$$
x=\frac{p_{2}-p_{1}}{2 t\left(s_{2}-s_{1}\right)}+\frac{s_{1}+s_{2}}{2}
$$

Based on (2), we may deduce the demand captured by each firm, as follows:

$$
Q_{1}\left(p_{1}, p_{2}\right)=\left\{\begin{array}{l}
0 \text { if } p_{1} \geq p_{1}^{\max } \\
x \text { if } p_{1}^{\max }>p_{1}>p_{1}^{\min } \\
1 \text { if } p_{1}^{\min } \geq p_{1}
\end{array} ; Q_{2}\left(p_{1}, p_{2}\right)=\left\{\begin{array}{l}
0 \text { if } p_{2} \geq p_{2}^{\max } \\
1-x \text { if } p_{2}^{\max }>p_{2}>p_{2}^{\text {min }} \\
1 \text { if } p_{2}^{\min } \geq p_{2}
\end{array}\right.\right.
$$

where:

$$
\begin{aligned}
& p_{1}^{\max }=p_{2}+t\left(s_{1}+s_{2}\right)\left(s_{2}-s_{1}\right) \\
& p_{1}^{\min }=p_{2}-t\left(s_{1}+s_{2}\right)\left(2-s_{2}-s_{1}\right) \\
& p_{2}^{\max }=p_{1}+t\left(s_{2}-s_{1}\right)\left(2-s_{1}-s_{2}\right) \\
& p_{2}^{\min }=p_{1}-t\left(s_{2}-s_{1}\right)\left(s_{1}+s_{2}\right)
\end{aligned}
$$

Note that the demand functions are piece-wise linear, continuous and concave in prices. It is this concavity that allows us to guarantee the existence of a Nash price equilibrium.

Following Liang and Mai (2006), we may analyse ex post subcontracting ${ }^{1}$. It is assumed that the decision to subcontract production of the intermediate input will be taken

\footnotetext{
${ }^{1}$ As Spiegel (1993) argues, ex post subcontracting can represent situations in which there is considerable uncertainty about either demand for the final good or the cost of marketing, and firms can learn their realisations only when they actually set downstream quantities. In fact, even when firms make a subcontracting agreement before competing in the market, they may wish to determine the actual volume subcontracted only ex post.
} 
after the pricing levels for the final product have been set. Specifically, then, we are assuming a game structured in three stages.

In the first stage, both firms simultaneously decide their locations in the market. In the second stage, they simultaneously set their prices for the final product, and in the third and final stage they enter into a subcontracting agreement, under which firm 2 produces $q_{s}$ units of input for firm 1, for which it receives a transfer payment.

Applying the backward induction method, we begin by analysing the optimum decision in the third stage of the game.

The decision to subcontract is assumed to be the outcome of a negotiated agreement which has two properties. On the one hand, the quantity subcontracted, $q_{s}$, is chosen in such a manner as to generate the maximum surplus. On the other, the transfer payment received by the subcontractor is determined by dividing the surplus between both firms in the proportions $\alpha$ and $(1-\alpha)$, respectively, where $\alpha \in[0,1]$ is a parameter denoting the bargaining power of firm 1 .

Given their locations and prices, both firms enter into a subcontracting agreement in order to maximise the possible surplus derived from the saving in joint costs. This is equivalent to characterize the solution of this negotiation using the Nash Bargaining Solution concept and to maximize the two firms joint profits difference between not having and having the subcontract, because firm's locations and mill prices and then the revenues are known in this stage.

This saving, S, is given by the difference between having and not having a subcontracting agreement. In formal terms:

$$
S=\left[c_{1}-c_{2}-t_{s}\left(s_{2}-s_{1}\right)^{2}\right] q_{s}
$$

where $t_{s}$ is the unit cost of transporting the input contracted. For the purposes of simplification, this parameter is normalised as one: $t_{s}=1$. Thus, the cost of transport per unit of distance between the location of one firm and that of a consumer, $t$, may likewise be interpreted as a transport cost ratio: $\frac{t}{t_{s}}$.

Meanwhile, it is assumed that the marginal cost of firm 1 is higher than the sum of firm 2's marginal cost and the transport cost of the input contracted. Under these conditions, differentiation of (3) indicates the variation in the surplus due to a change in the level of the input contracted: 


$$
\frac{\partial S}{\partial q_{s}}=c_{1}-c_{2}-\left(s_{2}-s_{1}\right)^{2}>0
$$

Hence, firm 1 will subcontract its entire production of the intermediate input to firm 2: $q_{s}=Q_{1}$, because this generates the largest possible surplus.

Having solved the last stage of the game, let us analyse the equilibrium in the second stage, in which the firms simultaneously set their prices for the final product, given their locations.

Given the optimum decision in the third stage, the profit functions of the firms may be split into two parts. On the one hand, we have the profit earned on the final product, and on the other the profit associated with the subcontracting agreement. Formally:

$$
\begin{aligned}
& \Pi_{1}=\left(p_{1}-c_{1}\right) Q_{1}+\alpha\left[c_{1}-c_{2}-\left(s_{2}-s_{1}\right)^{2}\right] Q_{1} \\
& \Pi_{2}=\left(p_{21}-c_{2}\right) Q_{2}+(1-\alpha)\left[c_{1}-c_{2}-\left(s_{2}-s_{1}\right)^{2}\right] Q_{1}
\end{aligned}
$$

Each firm has the objective of setting a price level that will maximise its individual profit, resulting in the following lemma:

\section{Lemma 1}

Given the locations $1 \leq s_{1}<s_{2}$, the Nash price equilibrium is given by:

$$
\begin{aligned}
& p_{1}^{*}=\frac{t\left(s_{2}-s_{1}\right)\left(2+s_{1}+s_{2}\right)+(3 \alpha-1)\left(s_{2}-s_{1}\right)^{2}+3\left[(1-\alpha) c_{1}+\alpha c_{2}\right]}{3} \\
& p_{2}^{*}=\frac{t\left(s_{2}-s_{1}\right)\left(4-s_{1}-s_{2}\right)+(3 \alpha-2)\left(s_{2}-s_{1}\right)^{2}+3\left[(1-\alpha) c_{1}+\alpha c_{2}\right]}{3} \\
& \text { if } \frac{\left(s_{2}-s_{1}\right)}{\left(2+s_{1}+s_{2}\right)}<t<\frac{\left(s_{2}-s_{1}\right)}{\left(s_{1}+s_{2}-4\right)}
\end{aligned}
$$

The Nash price equilibrium is given by:

$$
\begin{aligned}
& \tilde{p}_{1}=c_{2}+t\left(s_{2}-s_{1}\right)\left(s_{1}+s_{2}-2\right) \\
& \tilde{p}_{2}=c_{2} \\
& \text { if } t>\frac{\left(s_{2}-s_{1}\right)}{\left(s_{1}+s_{2}-4\right)}
\end{aligned}
$$

The Nash price equilibrium is given by:

$$
\begin{aligned}
& \hat{p}_{1}=c_{1} \\
& \hat{p}_{2}=c_{1}-t\left(s_{2}-s_{1}\right)\left(s_{1}+s_{2}\right)
\end{aligned}
$$


if $t<\frac{\left(s_{2}-s_{1}\right)}{\left(2+s_{1}+s_{2}\right)}$

Proof (see Appendix A).

From the above lemma, we may deduce that the participation of both firms in the market requires that the ratio of transport costs is bounded. If this ratio rises sufficiently, the market will be supplied exclusively by firm 1, which is valued more highly be all consumers.

Once prices are known, the firms simultaneously and individually decide on their respective locations in the market in the last stage of the game.

The concept of perfect equilibrium reflects the idea that the duopolists anticipate the consequences of their choice in the second stage for the decisions taken in the next stage. Hence, price competition will be more aggressive when the firms choose neary locations, and if product differentiation is greater, each firm's opportunities to enter the market occupied by its competitor will be reduced.

Using a reduced form of the profit functions, we have:

$$
\begin{aligned}
& \prod_{1}\left(s_{1}, s_{2}\right)=\left(p_{1}^{*}-c_{1}\right) Q_{1}\left(p_{1}^{*}, p_{2}^{*}, s_{1}, s_{2}\right)+\alpha\left[c_{1}-c_{2}-\left(s_{2}-s_{1}\right)^{2}\right] Q_{1}\left(p_{1}^{*}, p_{2}^{*}, s_{1}, s_{2}\right) \\
& \prod_{2}\left(s_{1}, s_{2}\right)=\left(p_{2}^{*}-c_{2}\right) Q_{2}\left(p_{1}^{*}, p_{2}^{*}, s_{1}, s_{2}\right)+(1-\alpha)\left[c_{1}-c_{2}-\left(s_{2}-s_{1}\right)^{2}\right] Q_{1}\left(p_{1}^{*}, p_{2}^{*}, s_{1}, s_{2}\right)
\end{aligned}
$$

Applying the envelope theorem, we can deduce that the effect of location on profit will be given, in part, by the sum of two effects with contrary signs, a direct effect (demand effect) and an indirect effect (strategic effect) via the competitor's prices, and in part by the influence of negotiating power. In formal terms, this decomposition is given for each firm by:

$$
\begin{aligned}
& \frac{d \prod_{1}}{d s_{1}}=\left\{p_{1}^{*}-c_{1}+\alpha\left[c_{1}-c_{2}-\left(s_{2}-s_{1}\right)^{2}\right]\right]\left[\frac{\partial Q_{1}}{\partial s_{1}}+\frac{\partial Q_{1}}{\partial p_{2}^{*}} \frac{\partial p_{2}^{*}}{\partial s_{1}}\right]+2 \alpha\left(s_{2}-s_{1}\right) Q_{1} \\
& \frac{d \prod_{2}}{d s_{2}}=\left\{p_{2}^{*}-c_{2}-(1-\alpha)\left[c_{1}-c_{2}-\left(s_{2}-s_{1}\right)^{2}\right]\left[\frac{\partial Q_{2}}{\partial s_{2}}+\frac{\partial Q_{2}}{\partial p_{1}^{*}} \frac{\partial p_{1}^{*}}{\partial s_{2}}\right]-2(1-\alpha)\left(s_{2}-s_{1}\right) Q_{1}\right.
\end{aligned}
$$


Based on this expression, we may observe that a higher value for $\alpha$ will provide firm 1 with an incentive to locate closer to its rival, while generating incentives for firm 2 to differentiate.

In this light, we may establish the following lemma:

\section{Lemma 2}

On the assumption that both firms capture market share, the Nash location equilibrium will be given by:

$$
s_{1}^{*}=\frac{t^{2}+19 t+3(3+t)(4-3 \alpha-\sqrt{\Delta})}{8 t(t+1)} ; s_{2}^{*}=\frac{19 t+9(4-3 \alpha)-9 \sqrt{\Delta}}{8 t}
$$

with $\Delta=t^{2}-2 t(9 \alpha-8)+(4-3 \alpha)^{2}$

$$
\forall \alpha>\frac{63+70 t-5 t^{2}}{36(3+t)} ; 0<t<1.8
$$

Proof (see Appendix B).

Based on this result, assuming that both firms are actives, the Nash equilibrium in the location sub-game is defined for a transport cost ratio lower than a given limit $(0<t<$ 1.8), and a sufficient bargaining power for firm $1(0.58<\alpha<1)$. Furthermore, we may analyse the effect of a change in each of these parameters on locations and, therefore, assess their influence on the degree of vertical differentiation. Specifically, the following proposition may be deduced:

\section{Proposition 1.}

The bargaining power of the consignor:

- positively affects the location of firm 1 and negatively affects the location of firm 2.

- Negatively influences the degree of differentiation.

The transport cost ratio:

- negatively influences the location of firm 1 and positively influences the location of firm 2.

- $\quad$ has a positive effect on the degree of differentiation.

Proof:

Based on the expressions for optimum location given in lemma 2, and for the range of variation in transport costs and bargaining power, the variation in each location with 
regard to these parameters is easily deduced. Specifically, the following relationships are obtained:

$$
\begin{aligned}
& \frac{\partial s_{1}^{*}}{\partial \alpha}>0 ; \frac{\partial s_{2}^{*}}{\partial \alpha}<0 ; \frac{\partial\left(s_{2}^{*}-s_{1}^{*}\right)}{\partial \alpha}<0 \\
& \frac{\partial s_{1}^{*}}{\partial t}<0 ; \frac{\partial s_{2}^{*}}{\partial t}>0 ; \frac{\partial\left(s_{2}^{*}-s_{1}^{*}\right)}{\partial t}>0
\end{aligned}
$$

From (14) it follows that greater bargaining power on the part of the consignor will mean the demand effect dominates over the strategic effect, resulting in a more aggressive behaviour by both duopolists. The combination of the two, meanwhile, will reduce the degree of differentiation the greater the consignor's bargaining power.

The opposite conclusion follows from (15). The transport cost ratio provides the firms with an incentive for differentiation, because the strategic effect predominates over the demand effect. Hence, the higher the transport cost, the greater the degree of differentiation.

\section{To subcontract or not to subcontract}

So far, we have assumed that firm two provides its rival with intermediate input. This decision will be valid, however, only if the profit earned from vertical subcontracting is higher than earnings in the absence of subcontracting (vertical foreclosure).

In the latter case, the third stage disappears, and the game is reduced to a two-stage decision process, in which the firms first choose their location and then compete in prices.

In the absence of subcontracting, each firm's profit will be given by:

$$
\prod_{i}=\left(p_{i}-c_{i}\right) Q_{i}^{F} ; \mathrm{i}=1,2
$$

where the superscript "F" indicates the absence of subcontracting (vertical foreclosure).

Applying the backward induction method once again to repeat the previous analysis, we may deduce that the optimum locations in the absence of subcontracting in the interval in which both firms capture market share are given by the following expressions:

$$
s_{1}^{F}=1 ; s_{2}^{F}=\frac{1}{3}\left(4+\sqrt{\frac{t-3\left(c_{1}-c_{2}\right)}{t}}\right) \forall \mathrm{t}>3\left(c_{1}-c_{2}\right)
$$

This results in the following profit for firm 2: 


$$
\prod_{2}^{F}=\frac{8\left[t+3\left(c_{1}-c_{2}\right)+\sqrt{t\left(t-3\left(c_{1}-c_{2}\right)\right.}\right]}{243\left[t+\sqrt{t\left(t-3\left(c_{1}-c_{2}\right)\right.}\right]}
$$

Our objective is to examine the intermediate input producer's decision to accept the subcontracting agreement in the extreme case in which firm 1 has total bargaining power. Substituting the value $\alpha=1$ into the expressions given in lemma 2, it follows that the optimum locations for the firms are:

$$
s_{1}^{*}=\frac{9-t}{4 t} ; s_{2}^{*}=\frac{5 t+9}{4 t}
$$

And the profit for firm 2 is:

$$
\Pi_{2}^{*}=\frac{3(t-1)^{2}}{4 t} ; \forall 1<t<1.8
$$

Based on the above expressions, we may deduce the conditions in which firm 2 will have incentives to accept the subcontracting agreement and, in that case, what the effect on the degree of product differentiation will be. Specifically, the following propositions are deduced:

Proposition 2

Assuming that firm 1 has total bargaining power,

$$
\begin{aligned}
& \prod_{2}^{*}<\prod_{2}^{F} \forall 1<t<1.421 \\
& \prod_{2}^{*}=\prod_{2}^{F} \quad \forall 1.21<t<1.721 \\
& \prod_{2}^{*}>\prod_{2}^{F} \forall 1.721<t<1.8
\end{aligned}
$$

Proof

From the comparison of (18) and (20), it follows that:

$$
\Pi_{2}^{*}-\prod_{2}^{F}=\frac{729-18 t\left[81+16\left(c_{1}-c_{2}\right)\right]+697 t^{2}-32 t^{1 / 2}\left[t-3\left(c_{1}-c_{2}\right)\right]^{3 / 2}}{972 t}
$$

Analysing this expression, we may conclude that it is positive for any $1.721<t<$ 1.8, regardless of the value exhibited by the difference between marginal costs. In the variation interval $1<t<1.421$, expression (21) is clearly negative, and in the interval 1.421 
$<t<1.721$ it may be either positive or negative depending on the difference between marginal production costs. Thus, where the values for the ratio of transport costs are close to the lower limit of the interval, firm 2 will accept a subcontracting agreement if the difference between marginal costs is narrow. Where this ratio is close to the upper limit, however, the firm will have incentives to enter into an agreement in the case of a greater asymmetry between marginal costs. Figures 1-a, 1-b, 1-c and 1-d reflect the evolution of the difference between profits $\prod_{2}^{*}-\prod_{2}^{F}$ based on the divergence between marginal costs $\left(c_{1}-c_{2}\right)$ for the transport cost values $t=1.25, t=1.75, t=1.45$ and $t=1.55$, respectively.

$$
\Pi_{2}^{*}-\Pi_{2}^{F}
$$

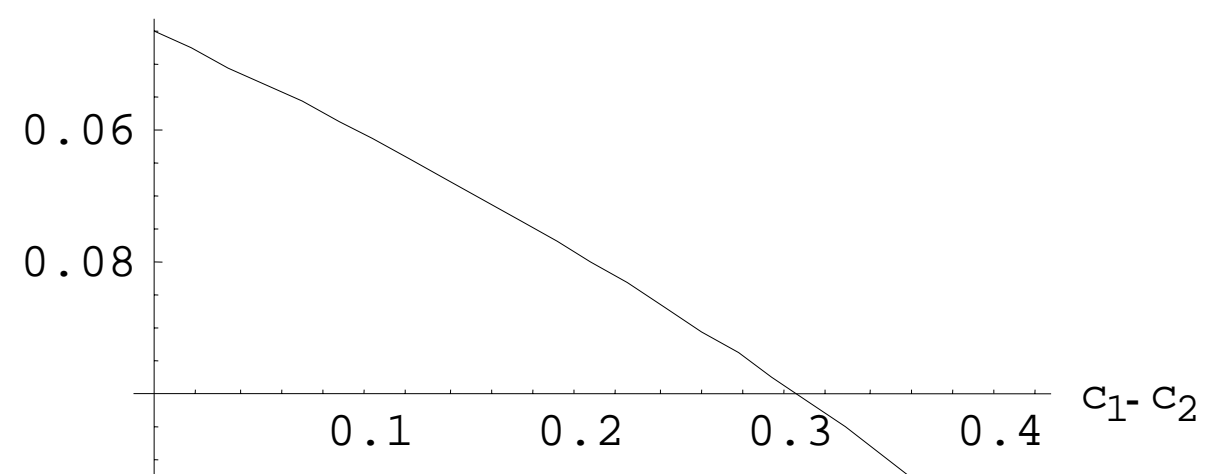

0.12

Figure 1-a (Difference of profits for $t=1.25)$ 


$$
\Pi_{2}^{*}-\Pi_{2}^{F}
$$

.12

$\odot .1$

.08

.06

.04

.02

$$
\begin{array}{llllll}
0.1 & 0.2 & 0.3 & 0.4 & 0.5 & \mathrm{C}_{1-} \mathrm{C}_{2}
\end{array}
$$

Figure 1-b (Difference of profits for $\mathrm{t}=1.75$ )

$$
\Pi_{2}^{*}-\Pi_{2}^{F}
$$

$$
\begin{array}{lllll}
0.1 & 0.2 & 0.3 & 0.4 & c_{1-} c_{2}
\end{array}
$$

$\odot .02$

0.04

0.06

$\odot . \odot 8$

Figure 1-c (Difference of profits for $\mathrm{t}=1.45$ ) 


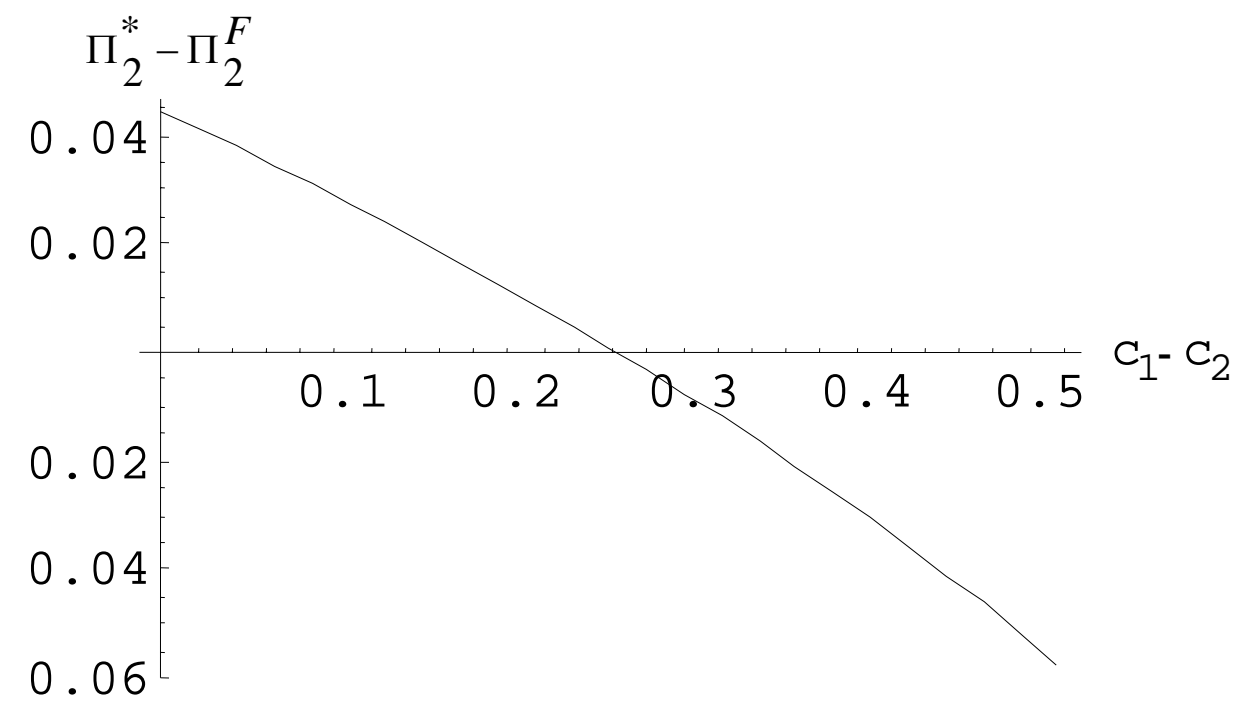

Figure 1-d (Difference of profits for $t=1.55)$

Proposition 3

Assuming that firm 1 has total bargaining power, subcontracting implies more distant locations from the interval in which consumers are distributed and a higher degree of vertical differentiation.

Proof

Based on expressions (17) and (19), it plainly follows that:

$$
s_{1}^{*}>s_{1}^{F} \mathrm{ys}_{2}^{*}>s_{2}^{F} ; \forall 1<t<1.8
$$

Hence, subcontracting will lead the firms to choose a location that is further from the interval in which consumers are distributed.

Similarly, it follows for the interval of the variation in transport costs considered that:

$$
s_{2}^{*}-s_{1}^{*}>s_{2}^{F}-s_{1}^{F}
$$

and the degree of differentiation will therefore be greater under a subcontracting agreement than in the absence of the same.

\section{Conclusions}

Subcontracting of all or part of production is a common form of relationship between rival firms in numerous industries, and the practice conditions their market 
behaviour. In this paper, we have examined the effects of subcontracting on the degree of vertical product differentiation. For this purpose, a version of the Hotelling spatial competition model was developed, in which two rival firms related through subcontracting of an intermediate input establish their locations outside the interval in which consumers are distributed.

Obtaining the perfect equilibrium in a game in which the firms decide their locations in the first stage, then go on to compete on price and finally determine the volume of the input contracted, the following conclusions were obtained.

In the first place, the consignor will have a greater incentive to locate further from the market the greater its bargaining power, while adopting a more aggressive stance in the pricing stage. In contrast, an increase in the consignor's bargaining power provides an incentive for its rival to locate closer to the market, allowing it to set a higher price. This means that the degree of differentiation will be less the greater the relative participation of the consignor in the distribution of the surplus generated by subcontracting.

In terms of product differentiation, this result implies that the consignor's bargaining power reduces the quality of the product rated most highly by consumers and raises that of the lower quality product, thereby narrowing the quality gap.

Secondly, a higher value for the ratio of final product and intermediate input transport costs increases the degree of differentiation between product varieties. In this case, both firms tend to differentiate in order to avoid aggressive behaviour at the price setting stage.

Thus, the model reproduces earlier conclusions of Liang and Mai (2006) in the context of horizontal product differentiation, where the Principle of Maximum Differentiation occurs if this ratio is sufficiently small.

Thirdly, if we assume that the consignor has total bargaining power, the subcontractor will always accept an agreement given a sufficiently high value for the ratio between final product and intermediate input transport costs. In this situation, subcontracting implies locations that are more distant from the market than would be the case in its absence (vertical foreclosure).

Reasoning from the standpoint of product differentiation, subcontracting once again reduces the level of quality (the high and the low quality) and gives rise to a higher degree of differentiation. 


\section{Appendix}

\section{A. Proof of lemma 1}

Let $\left(p_{1}^{*}, p_{2}^{*}\right)$ be a vector of equilibrium prices (since the profit functions are quasi-concave, we know that a price equilibrium exists), and let us further assume that (7) holds. In the domain:

$D_{1}=\left\{\left(p_{1}, p_{2}\right) / Q_{1}\left(p_{1}, p_{2}\right)>0, Q_{2}\left(p_{1}, p_{2}\right)>0\right\}$

the firms' demand functions are given by:

$Q_{1}=\frac{p_{2}-p_{1}}{2 t\left(s_{2}-s_{1}\right)}+\frac{s_{1}+s_{2}}{2} ; Q_{2}=\frac{p_{1}-p_{2}}{2 t\left(s_{2}-s_{1}\right)}+\frac{2-s_{1}-s_{2}}{2}$

If $\left(p_{1}^{*}, p_{2}^{*}\right) \in D_{1},\left(p_{1}^{*}, p_{2}^{*}\right)$ should satisfy the first order conditions, $\frac{\partial \prod_{i}}{\partial p_{i}}=0, i=1,2$.

Hence, we may deduce the expressions:

$$
\begin{aligned}
& p_{1}^{*}=\frac{t\left(s_{2}-s_{1}\right)\left(2+s_{1}+s_{2}\right)+(3 \alpha-1)\left(s_{2}-s_{1}\right)^{2}+3\left[(1-\alpha) c_{1}+\alpha c_{2}\right]}{3} \\
& p_{2}^{*}=\frac{t\left(s_{2}-s_{1}\right)\left(4-s_{1}-s_{2}\right)+(3 \alpha-2)\left(s_{2}-s_{1}\right)^{2}+3\left[(1-\alpha) c_{1}+\alpha c_{2}\right]}{3}
\end{aligned}
$$

If (7) holds, then it follows that $\left(p_{1}^{*}, p_{2}^{*}\right) \in D_{1}$ and $\left(p_{1}^{*}, p_{2}^{*}\right)>0$. For this price vector to constitute a Nash equilibrium, we need to verify that $\prod_{i}\left(p_{i}^{*}, p_{j}^{*}\right)>\prod_{i}\left(\bar{p}_{i}, p_{j}^{*}\right)$, where $\bar{p}_{i}$ is the best response for firm $\mathrm{i}$ in the case of $p_{j}^{*}$ in the domain $A_{i}=\left\{p_{i} / Q_{j}\left(p_{i}, p_{j}^{*}\right)=0\right\}$ for $\mathrm{i}, \mathrm{j}=1,2, \mathrm{i} \neq \mathrm{j}$.

Let $\mathrm{i}=1$. In this case

$$
\bar{p}_{1}=\frac{2 t\left(s_{2}-s_{1}\right)\left(s_{1}+s_{2}-1\right)+(3 \alpha-2)\left(s_{2}-s_{1}\right)^{2}+3\left[(1-\alpha) c_{1}+\alpha c_{2}\right]}{3}
$$

Assuming (7) holds, it follows that $\prod_{1}\left(p_{1}^{*}, p_{2}^{*}\right)>\prod_{1}\left(\bar{p}_{1}, p_{2}^{*}\right)$.

Likewise, we may deduce that if (7) holds, then $\Pi_{2}\left(p_{1}^{*}, p_{2}^{*}\right)>\Pi_{1}\left(\bar{p}_{2}, p_{1}^{*}\right)$ where

$$
\bar{p}_{2}=\frac{2 t\left(s_{2}-s_{1}\right)\left(1-s_{1}-s_{2}\right)+(3 \alpha-1)\left(s_{2}-s_{1}\right)^{2}+3\left[(1-\alpha) c_{1}+\alpha c_{2}\right]}{3}
$$

Let us now assume that (8) holds. In this case, the vector $\left(p_{1}^{*}, p_{2}^{*}\right)$ will belong to the domain: $D_{2}=\left\{\left(p_{1}, p_{2}\right) / Q_{1}\left(p_{1}, p_{2}\right)=1\right\}$. Meanwhile, $\tilde{p}_{2}=c_{2}$ must hold, because if it 
does not firm 2 can always lower its price and gain market share. Price $\tilde{p}_{1}=c_{2}+t\left(s_{2}-s_{1}\right)\left(s_{1}+s_{2}-2\right)$ predominates over any $p_{1}<\tilde{p}_{1}$.

Finally, let us assume that (9) holds. The price vector $\left(p_{1}^{*}, p_{2}^{*}\right)$ belongs to the domain: $D_{3}=\left\{\left(p_{1}, p_{2}\right) / Q_{2}\left(p_{1}, p_{2}\right)=1\right\}$. The price set by firm 1 must be $\hat{p}_{1}=c_{1}$, because otherwise the firm can always lower its price and gain market share. The maximum price that would allow firm 2 to capture the whole of demand is: $\hat{p}_{2}=c_{1}-t\left(s_{2}-s_{1}\right)\left(s_{1}+s_{2}\right)$.

\section{B. Proof of lemma 2}

Assuming that both firms compete in the market ((7) holds), the substitution of the equilibrium prices in equations (5) and (6) allows the definition of both firms' profit based on their locations. Specifically, the following expressions are obtained:

$$
\begin{aligned}
& \Pi_{1}=\frac{\left(s_{2}-s_{1}\right)\left[t\left(2+s_{1}+s_{2}\right)-\left(s_{2}-s_{1}\right)\right]^{2}}{18 t} \\
& \prod_{2}=\frac{\left[t\left(s_{2}-s_{1}\right)\left(4-s_{1}-s_{2}\right)+(3 \alpha-2)\left(s_{2}-s_{1}\right)^{2}+3(1-\alpha)\left(c_{1}-c_{2}\right)\right]\left[t\left(4-s_{1}-s_{2}\right)+s_{2}-s_{1}\right]}{18 t}+ \\
& +\frac{(1-\alpha)\left[t\left(2+s_{1}+s_{2}\right)-\left(s_{2}-s_{1}\right)\right]\left[c_{1}-c_{2}-\left(s_{2}-s_{1}\right)^{2}\right]}{6 t}
\end{aligned}
$$

Each firm decides the value of the location, such that it maximises individual profit, given the location of its rival. Based on the first order conditions, the reaction function of firm 1 may be deduced:

$$
s_{1}=\frac{(t+3) s_{2}-2 t}{3(t+1)}
$$

The maximisation of (B.2), taking into account (B.3), results in the locations:

$$
s_{2}=\frac{19 t+9(4-3 \alpha) \pm \sqrt{\Delta}}{8 t} \text {, with } \Delta=t^{2}-2 t(9 \alpha-8)+(4-3 \alpha)^{2}
$$

of which only $s_{2}^{*}=\frac{19 t+9(4-3 \alpha)-\sqrt{\Delta}}{8 t}$ is a maximum compatible the validation of (7).

Introducing $s_{2}^{*}$ in (B.3), the optimum location of firm 1 can be determined:

$$
s_{1}^{*}=\frac{t^{2}+19 t+3(3+t)(4-3 \alpha-\sqrt{\Delta})}{8 t(t+1)} .
$$


Taking into account both locations, restriction (7) results in the verification of the inequality: $\alpha>\frac{63+70 t-5 t^{2}}{36(3+t)}$ which in turn determines the range of variation in the transport costs ratio: $0<t<1.8$ given rise to the interval of bargaining power: $0.58<\alpha<1$. 


\section{References}

Gabszewicz, J. and Thisse, J-F. 1986. On the Nature of Competition with Differentiated Products. The Economic Journal 96:160-172.

Holmes, J. 1986 The Organization and Locational Structure of Production Subcontracting. In A.J. Scott and M. Storper (eds), Production, Work, and Territory: The Geographical Anatomy of Industrial Capitalism. Boston; London and Sidney: Allen \& Unwin.: 80-106.

Hotelling, H. 1929. Stability in Competition. The Economic Journal 39: 41-53.

Kamien, M.I., Li, L. and Samet, D. 1989. Bertrand Competition with Subcontracting. RAND Journal of Economics 20: 553-567.

Lewis, T.R. and Sappington, D.E.M. 1989. Technological Change and the Boundaries of the Firm. American Economic Review 81: 887-900.

Liang, W-J., and Mai, Ch. 2006. Validity of the Principle of Minimum Differentiation under Vertical Subcontracting. Regional Science and Urban Economics 36: 373-384.

Scott, A.J. 1991. Electronics assembly subcontracting in southern California: production process, employment, and location. Growth and Change, 22-35.

Spiegel, Y. 1993. Horizontal Subcontracting. RAND Journal of Economics 24: 570-590.

Taymaz, E. and Kilicaslan, Y. 2002. Subcontracting Dynamics and Economic Development: A Study on Textile and Engineering Industries. ERC Working Papers in Economics 01/08.

Wang, C.L., Kuo, N.F., and Chan, L.Y. 2002: Outsourcing of the manufacturing industries and agglomeration: the case with Taiwan's 1991 Census Data. The 2002 Annual Meeting of Taiwan Economic Association. 
DOCUMENTOS DE TRABAJO

Facultad de Ciencias Económicas y Empresariales

Universidad de Zaragoza

2002-01: "Evolution of Spanish Urban Structure During the Twentieth Century". Luis Lanaspa, Fernando Pueyo y Fernando Sanz. Department of Economic Analysis, University of Zaragoza.

2002-02: "Una Nueva Perspectiva en la Medición del Capital Humano”. Gregorio Giménez y Blanca Simón. Departamento de Estructura, Historia Económica y Economía Pública, Universidad de Zaragoza.

2002-03: "A Practical Evaluation of Employee Productivity Using a Professional Data Base”. Raquel Ortega. Department of Business, University of Zaragoza.

2002-04: "La Información Financiera de las Entidades No Lucrativas: Una Perspectiva Internacional”. Isabel Brusca y Caridad Martí. Departamento de Contabilidad y Finanzas, Universidad de Zaragoza.

2003-01: "Las Opciones Reales y su Influencia en la Valoración de Empresas". Manuel Espitia y Gema Pastor. Departamento de Economía y Dirección de Empresas, Universidad de Zaragoza.

2003-02: "The Valuation of Earnings Components by the Capital Markets. An International Comparison”. Susana Callao, Beatriz Cuellar, José Ignacio Jarne and José Antonio Laínez. Department of Accounting and Finance, University of Zaragoza.

2003-03: "Selection of the Informative Base in ARMA-GARCH Models". Laura Muñoz, Pilar Olave and Manuel Salvador. Department of Statistics Methods, University of Zaragoza.

2003-04: "Structural Change and Productive Blocks in the Spanish Economy: An Imput-Output Analysis for 1980-1994”. Julio Sánchez Chóliz and Rosa Duarte. Department of Economic Analysis, University of Zaragoza.

2003-05: "Automatic Monitoring and Intervention in Linear Gaussian State-Space Models: A Bayesian Approach”. Manuel Salvador and Pilar Gargallo. Department of Statistics Methods, University of Zaragoza.

2003-06: “An Application of the Data Envelopment Analysis Methodology in the Performance Assessment of the Zaragoza University Departments”. Emilio Martín. Department of Accounting and Finance, University of Zaragoza.

2003-07: "Harmonisation at the European Union: a difficult but needed task". Ana Yetano Sánchez. Department of Accounting and Finance, University of Zaragoza.

2003-08: "The investment activity of spanish firms with tangible and intangible assets". Manuel Espitia and Gema Pastor. Department of Business, University of Zaragoza. 
2004-01: "Persistencia en la performance de los fondos de inversión españoles de renta variable nacional (1994-2002)”. Luis Ferruz y María S. Vargas. Departamento de Contabilidad y Finanzas, Universidad de Zaragoza.

2004-02: "Calidad institucional y factores político-culturales: un panorama internacional por niveles de renta”. José Aixalá, Gema Fabro y Blanca Simón. Departamento de Estructura, Historia Económica y Economía Pública, Universidad de Zaragoza.

2004-03: “La utilización de las nuevas tecnologías en la contratación pública”. José Ma Gimeno Feliú. Departamento de Derecho Público, Universidad de Zaragoza.

2004-04: "Valoración económica y financiera de los trasvases previstos en el Plan Hidrológico Nacional español”. Pedro Arrojo Agudo. Departamento de Análisis Económico, Universidad de Zaragoza. Laura Sánchez Gallardo. Fundación Nueva Cultura del Agua.

2004-05: "Impacto de las tecnologías de la información en la productividad de las empresas españolas”. Carmen Galve Gorriz y Ana Gargallo Castel. Departamento de Economía y Dirección de Empresas. Universidad de Zaragoza.

2004-06: "National and International Income Dispersión and Aggregate Expenditures”. Carmen Fillat. Department of Applied Economics and Economic History, University of Zaragoza. Joseph Francois. Tinbergen Institute Rotterdam and Center for Economic Policy Resarch-CEPR.

2004-07: “Targeted Advertising with Vertically Differentiated Products”. Lola Esteban and José M. Hernández. Department of Economic Analysis. University of Zaragoza.

2004-08: "Returns to education and to experience within the EU: are there differences between wage earners and the self-employed?”. Inmaculada García Mainar. Department of Economic Analysis. University of Zaragoza. Víctor M. Montuenga Gómez. Department of Business. University of La Rioja

2005-01: "E-government and the transformation of public administrations in EU countries: Beyond NPM or just a second wave of reforms?”. Lourdes Torres, Vicente Pina and Sonia Royo. Department of Accounting and Finance.University of Zaragoza

2005-02: "Externalidades tecnológicas internacionales y productividad de la manufactura: un análisis sectorial”. Carmen López Pueyo, Jaime Sanau y Sara Barcenilla. Departamento de Economía Aplicada. Universidad de Zaragoza.

2005-03: "Detecting Determinism Using Recurrence Quantification Analysis: Three Test Procedures”. María Teresa Aparicio, Eduardo Fernández Pozo and Dulce Saura. Department of Economic Analysis. University of Zaragoza.

2005-04: "Evaluating Organizational Design Through Efficiency Values: An Application To The Spanish First Division Soccer Teams”. Manuel Espitia Escuer and Lucía Isabel García Cebrián. Department of Business. University of Zaragoza. 
2005-05: "From Locational Fundamentals to Increasing Returns: The Spatial Concentration of Population in Spain, 1787-2000”. María Isabel Ayuda. Department of Economic Analysis. University of Zaragoza. Fernando Collantes and Vicente Pinilla. Department of Applied Economics and Economic History. University of Zaragoza.

2005-06: "Model selection strategies in a spatial context". Jesús Mur and Ana Angulo. Department of Economic Analysis. University of Zaragoza.

2005-07: "Conciertos educativos y selección académica y social del alumnado". María Jesús Mancebón Torrubia. Departamento de Estructura e Historia Económica y Economía Pública. Universidad de Zaragoza. Domingo Pérez Ximénez de Embún. Departamento de Análisis Económico. Universidad de Zaragoza.

2005-08: "Product differentiation in a mixed duopoly". Agustín Gil. Department of Economic Analysis. University of Zaragoza.

2005-09: "Migration dynamics, growth and convergence”. Gemma Larramona and Marcos Sanso. Department of Economic Analysis. University of Zaragoza.

2005-10: “Endogenous longevity, biological deterioration and economic growth". Marcos Sanso and Rosa María Aísa. Department of Economic Analysis. University of Zaragoza.

2006-01: "Good or bad? - The influence of FDI on output growth. An industry-level analysis“. Carmen Fillat Castejón. Department of Applied Economics and Economic History. University of Zaragoza. Julia Woerz. The Vienna Institute for International Economic Studies and Tinbergen Institute, Erasmus University Rotterdam.

2006-02: "Performance and capital structure of privatized firms in the European Union”. Patricia Bachiller y $\mathrm{M}^{\mathrm{a}}$ José Arcas. Departamento de Contabilidad y Finanzas. Universidad de Zaragoza.

2006-03: "Factors explaining the rating of Microfinance Institutions". Begoña Gutiérrez Nieto and Carlos Serrano Cinca. Department of Accounting and Finance. University of Saragossa, Spain.

2006-04: “Libertad económica y convergencia en argentina: 1875-2000”. Isabel Sanz Villarroya. Departamento de Estructura, Historia Económica y Economía Pública. Universidad de Zaragoza. Leandro Prados de la Escosura. Departamento de $\mathrm{H}^{\mathrm{a}}$ e Instituciones Ec. Universidad Carlos III de Madrid.

2006-05: "How Satisfied are Spouses with their Leisure Time? Evidence from Europe*”. Inmaculada García, José Alberto Molina y María Navarro. University of Zaragoza.

2006-06: "Una estimación macroeconómica de los determinantes salariales en España (1980-2000)”. José Aixalá Pastó y Carmen Pelet Redón. Departamento de Estructura, Historia Económica y Economía Pública. Universidad de Zaragoza.

2006-07: "Causes of World Trade Growth in Agricultural and Food Products, 1951 2000". Raúl Serrano and Vicente Pinilla. Department of Applied Economics and Economic History, University of Zaragoza, Gran Via 4, 50005 Zaragoza (Spain). 
2006-08: "Prioritisation of patients on waiting lists: a community workshop approach”. Angelina Lázaro Alquézar. Facultad de Derecho, Facultad de Económicas. University of Zaragoza. Zaragoza, Spain. Begoña Álvarez-Farizo. C.I.T.A.- Unidad de Economía. Zaragoza, Spain

2007-01: "Deteminantes del comportamiento variado del consumidor en el escenario de Compra”. Carmén Berné Manero y Noemí Martínez Caraballo. Departamento de Economía y Dirección de Empresas. Universidad de Zaragoza.

2007-02: “Alternative measures for trade restrictiveness. A gravity approach". Carmen Fillat \& Eva Pardos. University of Zaragoza.

2007-03: "Entrepreneurship, Management Services and Economic Growth". Vicente Salas Fumás \& J. Javier Sánchez Asín. Departamento de Economía y Dirección de Empresas. University of Zaragoza.

2007-04: "Equality versus Equity based pay systems and their effects on rational altruism motivation in teams: Wicked masked altruism”. Javier García Bernal \& Marisa Ramírez Alerón. University of Zaragoza.

2007-05: "Macroeconomic outcomes and the relative position of Argentina's Economy: 1875-2000”. Isabel Sanz Villarroya. University of Zaragoza.

2008-01: "Vertical product differentiation with subcontracting” Joaquín Andaluz Funcia. University of Zaragoza. 